\title{
Impact of COVID-19-Related Traffic Slowdown on Urban Heat Characteristics
}

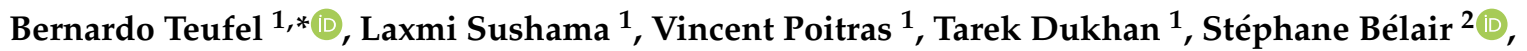 \\ Luis Miranda-Moreno ${ }^{1}$, Lijun Sun ${ }^{1}$, Agus P. Sasmito ${ }^{1} \mathbb{D}$ and Girma Bitsuamlak ${ }^{3}$ \\ 1 Trottier Institute for Sustainability in Engineering and Design, McGill Sustainability Systems Initiative, \\ McGill University, Montréal, QC H3A 0C3, Canada; laxmi.sushama@mcgill.ca (L.S.); \\ vincent.poitras@mcgill.ca (V.P.); tarek.dukhan@mail.mcgill.ca (T.D.); \\ luis.miranda-moreno@mcgill.ca (L.M.-M.); lijun.sun@mcgill.ca (L.S.); agus.sasmito@mcgill.ca (A.P.S.) \\ 2 Meteorological Research Division, Science and Technology Branch, \\ Environment and Climate Change Canada, Dorval, QC H9P 1J3, Canada; stephane.belair@canada.ca \\ 3 Department of Civil \& Environmental Engineering, University of Western Ontario, \\ London, ON N6A 5B9, Canada; gbitsuam@uwo.ca \\ * Correspondence: bernardo.teufel@mail.mcgill.ca
}

Citation: Teufel, B.; Sushama, L.; Poitras, V.; Dukhan, T.; Bélair, S.; Miranda-Moreno, L.; Sun, L.; Sasmito, A.P.; Bitsuamlak, G. Impact of COVID-19-Related Traffic Slowdown on Urban Heat Characteristics. Atmosphere 2021, 12, 243. https:// doi.org/10.3390/atmos12020243

Academic Editor: Clare Heaviside

Received: 3 February 2021

Accepted: 7 February 2021

Published: 11 February 2021

Publisher's Note: MDPI stays neutral with regard to jurisdictional claims in published maps and institutional affiliations.

Copyright: (c) 2021 by the authors. Licensee MDPI, Basel, Switzerland. This article is an open access article distributed under the terms and conditions of the Creative Commons Attribution (CC BY) license (https:// creativecommons.org/licenses/by/ $4.0 /)$.
Abstract: Governments around the world have implemented measures to slow down the spread of COVID-19, resulting in a substantial decrease in the usage of motorized transportation. The ensuing decrease in the emission of traffic-related heat and pollutants is expected to impact the environment through various pathways, especially near urban areas, where there is a higher concentration of traffic. In this study, we perform high-resolution urban climate simulations to assess the direct impact of the decrease in traffic-related heat emissions due to COVID-19 on urban temperature characteristics. One simulation spans the January-May 2020 period; two additional simulations spanning the April 2019-May 2020 period, with normal and reduced traffic, are used to assess the impacts throughout the year. These simulations are performed for the city of Montreal, the second largest urban centre in Canada. The mechanisms and main findings of this study are likely to be applicable to most large urban centres around the globe. The results show that an $80 \%$ reduction in traffic results in a decrease of up to $1^{\circ} \mathrm{C}$ in the near-surface temperature for regions with heavy traffic. The magnitude of the temperature decrease varies substantially with the diurnal traffic cycle and also from day to day, being greatest when the near-surface wind speeds are low and there is a temperature inversion in the surface layer. This reduction in near-surface temperature is reflected by an up to $20 \%$ reduction in hot hours (when temperature exceeds $30^{\circ} \mathrm{C}$ ) during the warm season, thus reducing heat stress for vulnerable populations. No substantial changes occur outside of traffic corridors, indicating that potential reductions in traffic would need to be supplemented by additional measures to reduce urban temperatures and associated heat stress, especially in a warming climate, to ensure human health and well-being.

Keywords: COVID-19; urban heat island; urban climate; regional climate model; anthropogenic heat; traffic

\section{Introduction}

COVID-19 emerged in late 2019 and was declared a pandemic by the World Health Organization on 11 March 2020. In an effort to slow down the spread of COVID-19, strict measures were put in place by many governments around the world, aiming to reduce the frequency and duration of in-person interactions. These measures have drastically altered patterns of human activity. For example, [1] found that surface transport activity decreased by $50 \%$, whereas industrial activity decreased by $35 \%$.

Some of the changes brought about by COVID-19 are likely to become permanent-for example, several major cities are rededicating street space for pedestrians and cyclists, and 
a number of companies will allow their employees to continue working remotely even after COVID-19 measures are discontinued. In this sense, COVID-19 represents an opportunity to explore which policies could potentially contribute to societal well-being and/or climate change adaptation and mitigation if made permanent.

The urban heat island (UHI) effect, as manifested by elevated near-surface air temperatures in urban areas compared to their non-urban surroundings, exposes urban dwellers to additional heat stress, especially during heat waves (e.g., [2]). Temperatures are generally higher in urban areas due to the urban geometry and the radiative and thermal properties of buildings and roads. The reduced vegetation in urban regions additionally reduces evaporative cooling. The UHI effect is further enhanced by heat emitted from transportation, heating, and air conditioning systems [3].

Given that global (and urban) temperatures are rising [4], reducing the intensity of the UHI effect is of vital importance across numerous urban centers, as the intensity of heat waves is projected to increase [5,6], resulting in additional heat stress and associated morbidity and mortality $[7,8]$. Measures that have been studied include increasing the reflectivity of urban regions and increasing vegetation [9-11]. A reduction in heat emitted from surface transportation would also be expected to reduce UHI intensity, and the measures put in place during the COVID-19 pandemic provide an opportunity to test this hypothesis. Although weather observation networks are denser near urban areas, a much higher density would be required to adequately capture the spatial structure of UHIs. Remote sensing can estimate surface temperatures at the spatial scales required to characterize UHIs, but this often only possible under clear-sky conditions [12], and the relationship between surface temperatures and near-surface air temperatures is not straightforward, with the latter being of much higher relevance for human well-being [13]. Furthermore, accurately estimating the impact of COVID-19 measures solely from observed data is difficult, given the great influence that natural variability has on climate observations.

The numerical models used to study the UHI effect and potential mitigation measures vary widely in both complexity and scale, from one-dimensional models used to assess various envelope materials at the building scale [10] and two-dimensional models describing heat and mass transfer at the urban canyon scale [9] to prognostic three-dimensional climate models at city to global scales [14]. Climate models have been refined over the past few decades to quantify the impact of both urban growth and climate change on the urban climate and to assess mitigation strategies. For example, increased greening and reflective surface coverings have the potential to jointly reduce urban air temperatures by around $2-3{ }^{\circ} \mathrm{C}[15,16]$. High-resolution regional climate model (RCM) simulations are particularly interesting in the study of urban regions and their climates, as they can represent the urban morphology at a finer scale [17-19] and improve on low resolution models which tend to underestimate urban temperatures, particularly in densely populated areas of cities, where the anthropogenic heat release is highest [14]. In this study, a high-resolution RCM is employed at the city level over Montreal to provide useful information on the impact of the COVID-19 pandemic on urban temperatures. To our knowledge, this is the first study to assess the direct impact of COVID-19 on urban temperatures, as previous studies on the environmental impacts of COVID-19 have focused on aerosols, greenhouse gases (GHGs), and other pollutants [1,20-26]. Here, we consider as direct impacts only those related to heat emissions, while indirect impacts occurring through the modification of atmospheric radiative properties by the decreased emission of aerosols and GHGs are outside the scope of this study.

The remainder of this manuscript is organized as follows: Section 2 describes the RCM and the simulations performed. Section 3 presents the validation of the RCM-simulated UHIs and describes how COVID-19 measures have impacted urban heat characteristics, including the implications for human well-being. Finally, Section 4 provides a summary and the main conclusions of the study. 


\section{Methods}

\subsection{Climate Model and Urban Representation}

The simulations in this study were performed using the limited-area version of the Global Environmental Multiscale (GEM; $[27,28])$ model, used for numerical weather prediction at Environment and Climate Change Canada (ECCC). It employs semi-Lagrangian transport and a (quasi) fully implicit time stepping scheme. In its fully elastic nonhydrostatic formulation [29], it uses a vertical coordinate based on hydrostatic pressure [30]. Condensation processes were computed by a double-moment microphysics scheme [31]. The land surface scheme used was CLASS v3.6 [32,33] and the urban scheme used was Town Energy Balance (TEB; [34]).

TEB is a physical scheme for urban energy budget based on a generalization of local canyon geometry. It is a single-layer urban canopy model. Buildings are assumed to be located along identical roads leading to the canyon structure. The lengths of the roads are considered to be far greater than their widths, any road orientation is possible, and all exist with the same probability. The buildings bordering the street canyon are assumed to have the same height and width within a model grid cell. In TEB, the urban morphology for each grid cell is defined in terms of the local building and road fractions, building height, building and canyon aspect ratio, and roughness length. The radiative characteristics such as albedos and emissivity for roofs, roads, and walls and thermal properties such as thermal conductivity and heat capacity of each roof, road, and wall layer are prescribed. TEB considers anthropogenic heat and moisture sources from combustion, split into two categories: traffic and industry. The traffic related fluxes are assumed to be released at the road level, while the industry fluxes are assumed to be released at the roof level.

\subsection{Urban Climate Simulations and Influence of COVID-19 on Traffic}

As mentioned in Section 1, one of the widely observed modifications of human behaviour due to the COVID-19 pandemic is a reduction in distance travelled. Prior to COVID-19, the average distance travelled by vehicles in Montreal was estimated at 43.19 million $\mathrm{km}$ per day, based on the citywide emissions of $3.567 \times 10^{9} \mathrm{~kg} \mathrm{CO}_{2}$ equivalent, an average consumption of $0.096 \mathrm{~L}$ of fuel per $\mathrm{km}$ driven, and the production of $2.357 \mathrm{~kg}$ of $\mathrm{CO}_{2}$ per liter of fuel consumed [35]. This estimate is consistent with previous research based on origin-destination surveys [36].

The spatial distribution of vehicle traffic was estimated from GPS trajectory data obtained by the City of Montreal during 2016 and 2017 as part of the MTL Trajet project [37]. A total of 58,792 trips by car were analyzed for a total distance driven of $653,962 \mathrm{~km}$ over $24,414 \mathrm{~h}$. This distance was distributed over the GEM grid by linking the GPS coordinates for each trip using straight lines and calculating the distance driven in each model grid cell. The prescribed anthropogenic heat fluxes due to traffic were obtained by scaling the fractional distance driven in each grid cell by the 43.19 million $\mathrm{km}$ driven per day and the production of 3.24 MJ sensible heat flux and 0.23 MJ latent heat flux per $\mathrm{km}$ driven [38]. The average sensible heat flux due to traffic is shown in Figure 1a, where highways and main roads can be clearly identified.

The temporal distribution of vehicle traffic was also estimated from the MTL Trajet data [37] using the start and end time of each trip. A traffic factor for each hour of the day was obtained (Figure 1b), revealing the morning ( 8 to 9 a.m.) and afternoon ( 5 to 6 p.m.) peaks of vehicular traffic. The highest value for the traffic factor (2.67) occurs during the afternoon peak, while the lowest (0.05) occurs overnight (4 to 5 a.m.). The variations in vehicular traffic at longer time scales (e.g., weekly and seasonal) are much smaller than this hourly variation and were omitted in this study for reasons of simplicity.

As the effect of decreased vehicular traffic on urban climate is likely to vary depending on the season, the urban climate simulations in this study cover the period from April 2019 to May 2020. The reference simulation (hereafter, GEM100) represents the business-as-usual case, with the anthropogenic heat fluxes due to traffic set to $100 \%$ of their reference values (Figure 1a). The reduced traffic simulation (hereafter, GEM20) represents the case where 
strict measures are in place to contain the spread of COVID-19, reducing traffic and its associated heat fluxes to $20 \%$ of their reference values. This $80 \%$ reduction is representative of the maximum expected reduction in distance travelled, which was estimated at an average of 76\% during the 28-day period from 25 March 2020 to 21 April 2020 for the Montreal region, based on the city-level mobility data [39].

A third simulation (GEM_COVID) approximates the timing of the implementation of COVID-19 measures in Montreal, which occurred in mid-to-late March 2020. Until 16 March, GEM_COVID follows the GEM100 reference. From 17 March onwards, the anthropogenic heat fluxes due to traffic are set to $20 \%$ of their reference values (as in GEM20).

All three urban climate simulations were performed at a $250 \mathrm{~m}$ horizontal grid spacing and were driven at the lateral boundaries by a GEM simulation at a 0.025 -degree $(\sim 3 \mathrm{~km})$ horizontal grid spacing covering southern Quebec (Figure 1c,d), which was in turn driven by the ERA5 reanalysis data [40]. The land cover and urban morphology fields used in all three simulations were derived from high-resolution datasets and provided directly by ECCC.
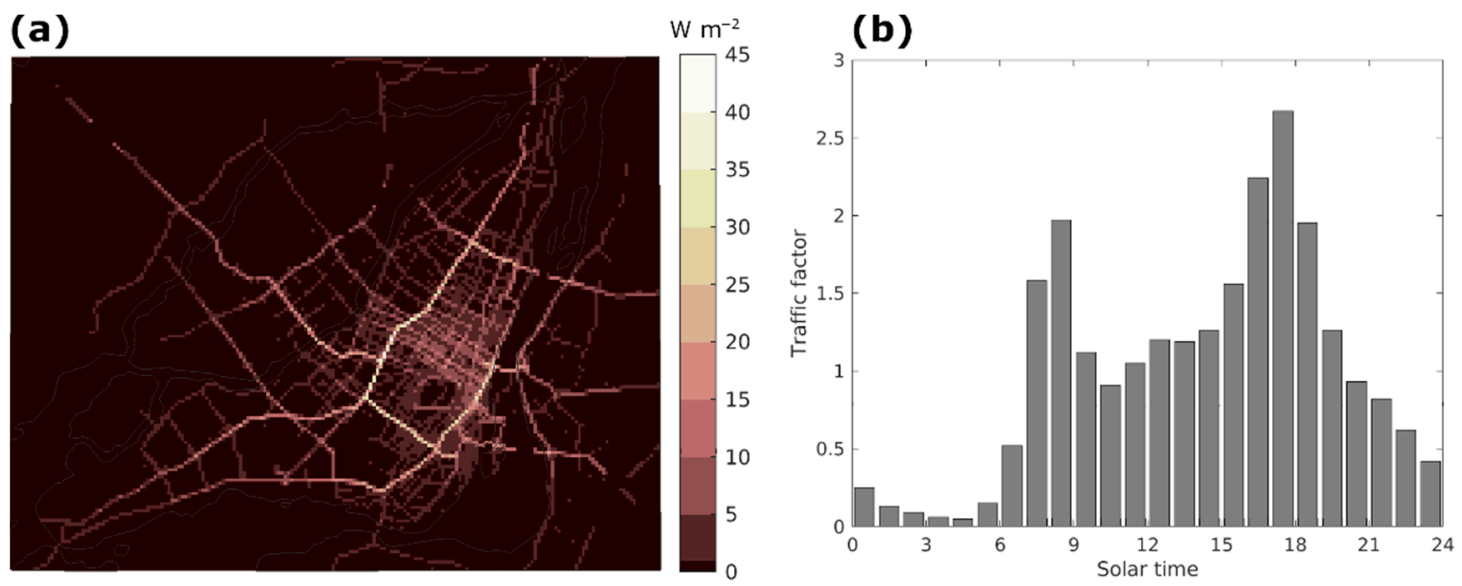

(c)

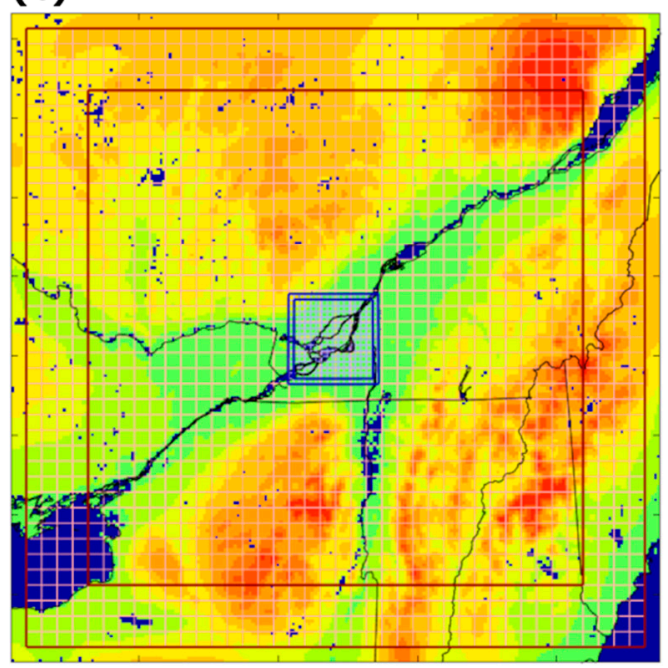

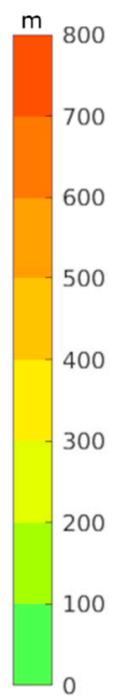

(d)

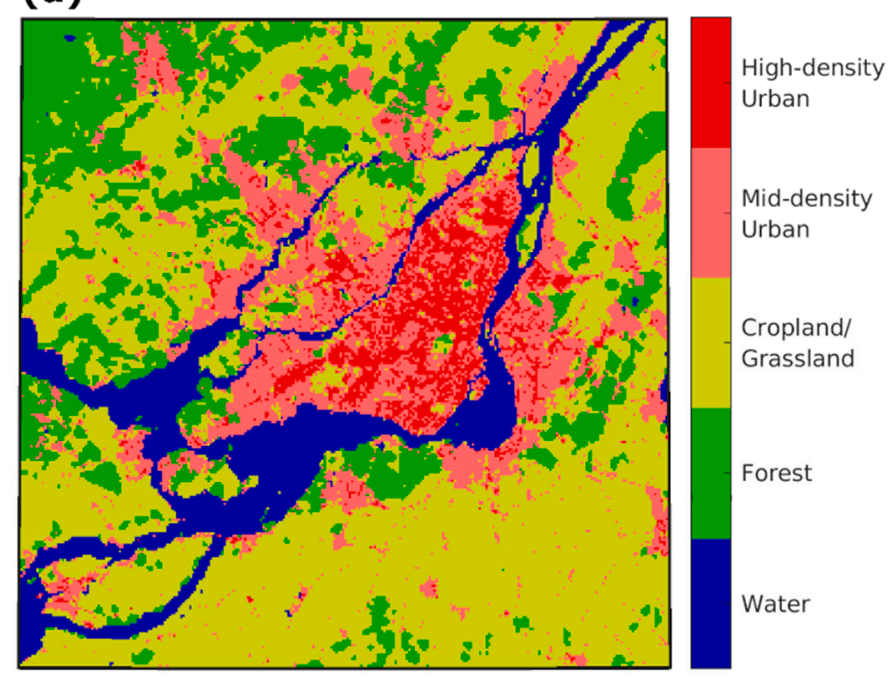

Figure 1. (a) Average anthropogenic sensible heat flux from traffic over Montreal. (b) Multiplicative factor for heat flux from traffic for each hour of the day. (c) Domains for GEM $2.5 \mathrm{~km}$ simulations (red; every 5th grid cell shown) and $250 \mathrm{~m}$ simulations (blue; every 20th grid cell shown). The outer thick lines represent the full domain, while the inner thick lines represent the free domain. Shading shows surface elevation and water bodies are shown in dark blue. (d) Predominant land cover in the $250 \mathrm{~m}$ domain. High-density urban is defined as urban fraction exceeding two thirds coverage, while mid-density urban is defined as the urban fraction with between one third and two thirds coverage. 


\subsection{Remote Sensing Data}

Land surface temperature (LST) products from satellite remote-sensing platforms are widely available and are potential sources for model validation, having comprehensive spatial coverage, comparable scale with models, and constant periodicity. The Moderate Resolution Imaging Spectroradiometer (MODIS) sensors onboard the Aqua satellite provide global coverage of LST over cloud-free regions two times per day. The satellite Sunsynchronous orbit of Aqua is designed to cross the equator at 13:30 and 1:30 (local solar time). The retrieved spatial resolution for LST is as high as $1 \mathrm{~km}$. In this study, the MYD21A1D and MYD21A1N collection 6 products are used, which contain LST for the day and night passes of Aqua, respectively, available from mid-2002 until the present. These products use the physics-based Temperature Emissivity Separation (TES) algorithm to dynamically retrieve both the LST and emissivity simultaneously for three thermal infrared bands. Validation has shown consistent accuracies at the $1{ }^{\circ} \mathrm{C}$ level over all land surface types including vegetation, water, and deserts [12].

\section{Results and Discussion}

\subsection{Model Validation}

Urban climate simulations over several regions using GEM have been validated in previous studies $[17,41-43]$. To assess whether GEM is able to capture the spatiotemporal variability of LST over the study region, the LST estimated by MODIS over heavily urbanized areas (urban fraction $>50 \%$ ) is first directly compared to the LST modelled by GEM. The day-to-day comparison over the entire simulation period is shown in Figure 2, for the daytime (around 1 p.m. local time) and nighttime (around 2 a.m. local time) overpasses of MODIS. It can be seen that GEM is able to capture both the daytime and nighttime LST temperatures. The MODIS daytime LST temperatures are known for occasionally containing unrealistically high values, which is related to the larger differences with respect to GEM for the 1 p.m. overpass. The reduced frequency of the MODIS data during the cold season can be explained by the more abundant cloud cover during this season, which prevents MODIS from observing the surface. The influence of cloud cover can also be seen during the warm season, during which MODIS is unable to capture the occasionally colder daytime LST temperatures, as these occur during cloudy days. The differences between GEM and MODIS are consistent with the biases reported by previous urban modelling studies over the region $[19,42]$.

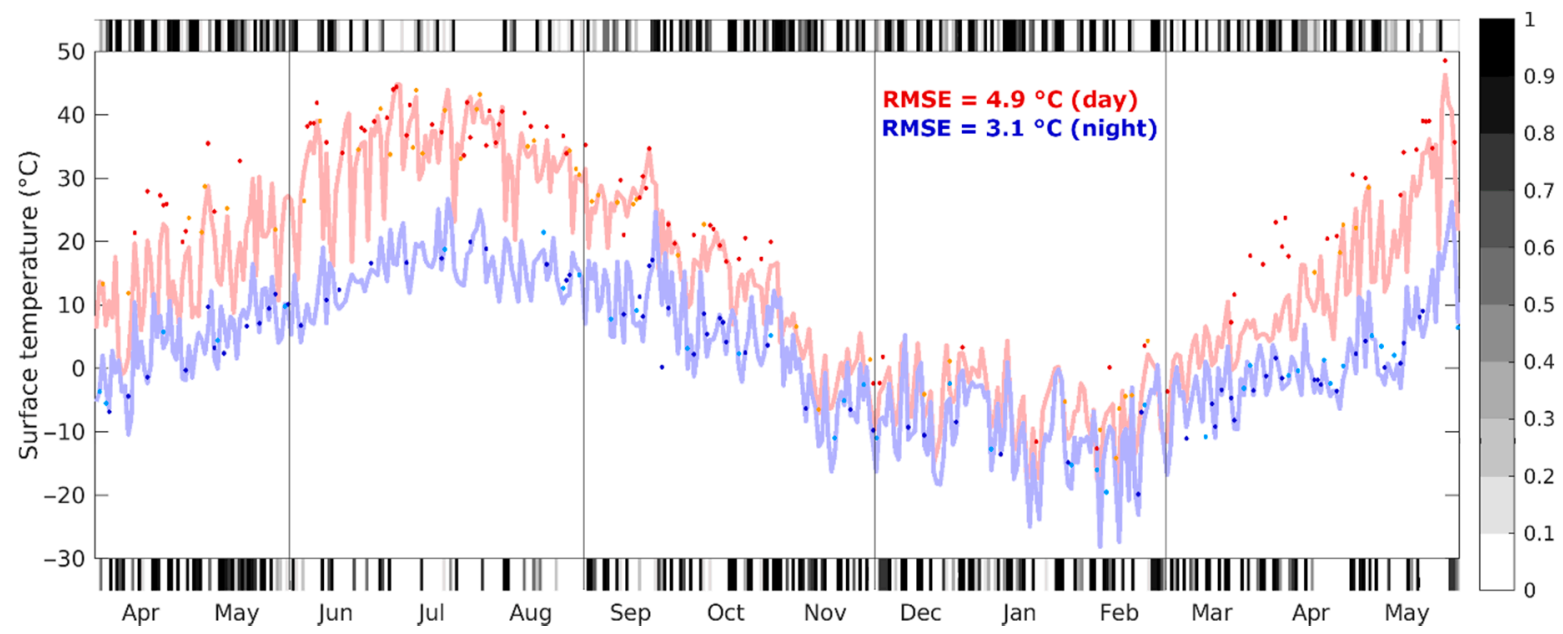

Figure 2. Daily evolution of surface temperature over predominantly urban grid cells in GEM (solid lines), compared to MODIS estimates (coloured dots), for the April 2019-May 2020 period. Daytime temperatures (GEM: 1 p.m.) are shown in red and nighttime temperatures (GEM: 2 a.m.) in blue. Gray shading on top (bottom) denotes the cloud fraction in GEM at 1 p.m. (2 a.m.). For the MODIS data, darker colors denote that at least two thirds of the urban region has valid data, while lighter colors are used when between one third and two thirds of the urban region has valid data. 
Given that the UHI and its effects on human health are strongest during the warm season daytime, the magnitude of the UHI estimated by MODIS and modelled by GEM are compared (Figure 3). Here, UHI is defined as the temperature difference with respect to the average over non-urbanized land areas (urban fraction $<1 \%$ ) in the simulation domain. The higher daytime LSTs over urban areas clearly stand out in both MODIS (Figure 3a) and GEM (Figure 3b), with the LST being around $10{ }^{\circ} \mathrm{C}$ higher in urban areas than in non-urban regions. Within urban areas, colder regions corresponding to greener areas (Figure $1 \mathrm{~d}$ ) can also be seen in both datasets. The same is true for water bodies (Figure 1d), which are much colder than urban and non-urban land areas in both datasets.

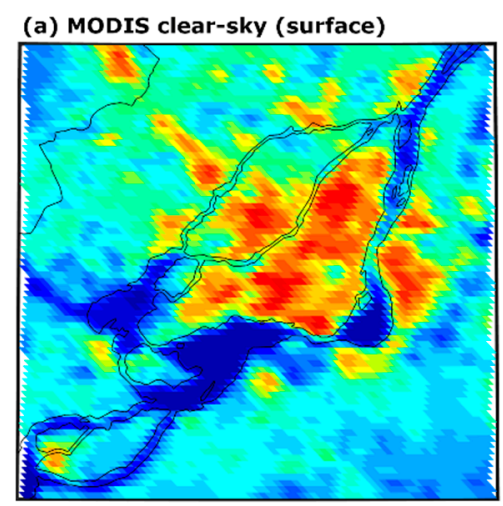

(b) GEM clear-sky (surface)
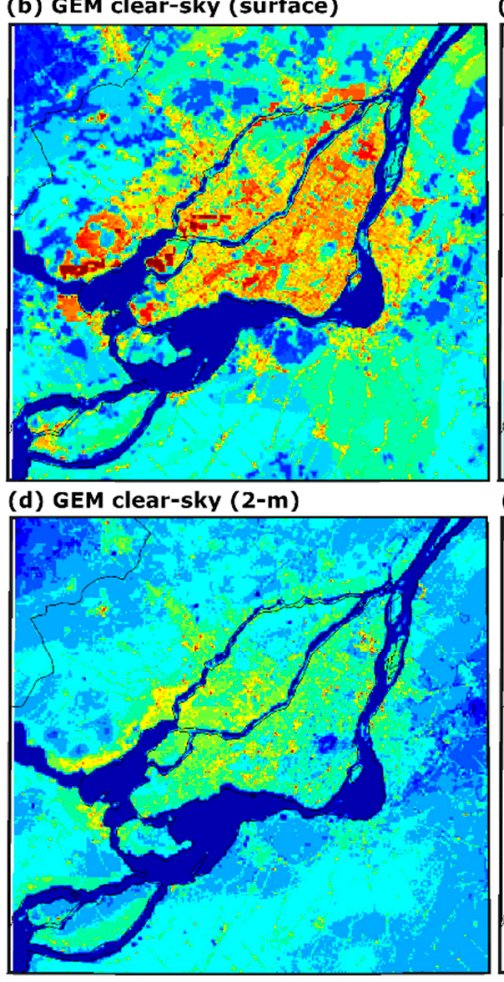

(c) GEM cloudy (surface)

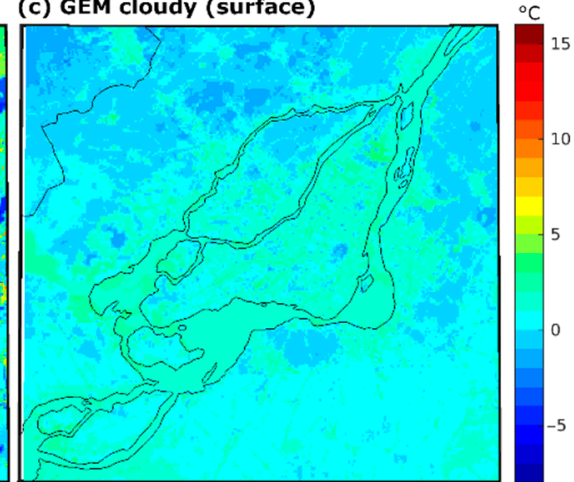

(e) GEM cloudy (2-m)

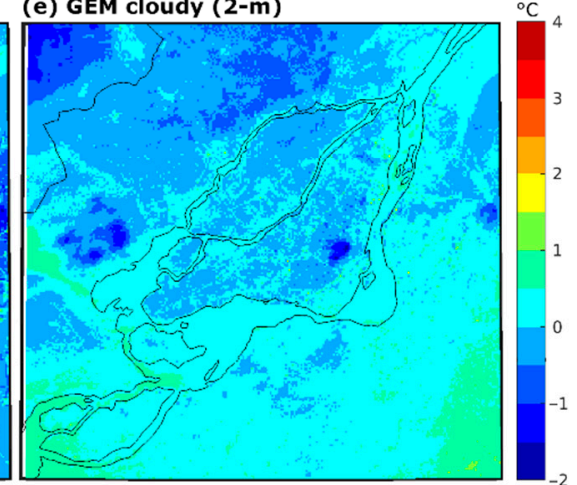

Figure 3. Magnitude of the surface urban heat island (UHI) during summer (JJA) in (a) MODIS and (b) the GEM100 simulation in daytime clear-sky conditions (GEM: 1 p.m., cloud fraction $<5 \%$ between noon and 1 p.m.). (c) Same as (b), but for cloudy conditions (cloud fraction $>80 \%$ ). (d) Magnitude of the $2 \mathrm{~m}$ temperature UHI at 1 p.m. in clear-sky conditions. (e) Same as (d), but for cloudy conditions.

During cloudy days, GEM models a much weaker surface UHI (Figure 3c), consistent with the reduced differential heating of urban and non-urban areas by solar radiation. While data to directly validate the $2 \mathrm{~m}$ temperature UHI do not exist, it can be seen that GEM produces patterns resembling the surface UHI, both during clear-sky (Figure 3d) and cloudy (Figure 3e) conditions. In addition, the magnitude of the $2 \mathrm{~m}$ temperature UHI is substantially lower than the surface UHI and is consistent with previous literature [13,14].

In addition to the validation of LST presented above, the $2 \mathrm{~m}$ air temperature was validated using hourly data from eight observation stations in the study domain (Figure 4a), available from ECCC. The data recorded at each station were compared directly to the $2 \mathrm{~m}$ temperature of the GEM grid cell in which the station was located. During the simulation period (April 2019-May 2020), the average bias across stations in GEM ranged from $-0.3{ }^{\circ} \mathrm{C}$ to $-1.4{ }^{\circ} \mathrm{C}$, while the root mean square error varied between $2.0^{\circ} \mathrm{C}$ and $2.6^{\circ} \mathrm{C}$, suggesting that GEM adequately captures both the mean and variability of the $2 \mathrm{~m}$ air temperature. The bias at each station was further analysed for each hour of the day and each season of the year (Figure $4 b$ ), revealing that GEM performs remarkably well for the summer daytime (from 6 a.m. to 6 p.m. local time) $2 \mathrm{~m}$ temperature, where 
the mean difference between the observed and modelled temperature was less than $1{ }^{\circ} \mathrm{C}$ for all hours and all stations. Averaging the bias at each station over a 30-day moving window (Figure 4c) shows that during most of the simulation, the bias stayed close to the mean, except during January 2020, where all stations except WVQ and WIZ (which are less urbanized) showed a stronger cold bias, possibly related to snow removal operations, which favor warmer temperatures but are not enabled in TEB for this study. The excellent performance demonstrated by GEM for the summer daytime is important, given that the strongest impacts of the UHI effect on human health (due to heat stress) occur during that time.

(a)

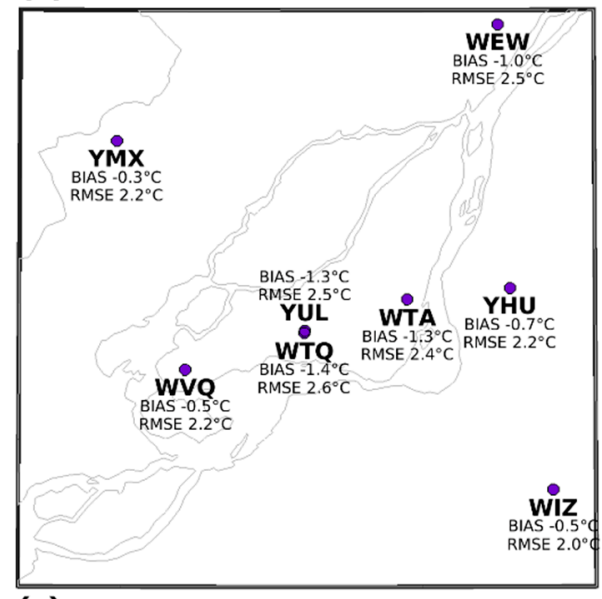

(c)

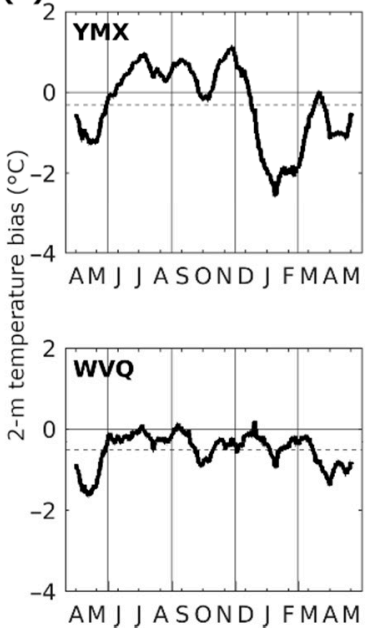

(b)

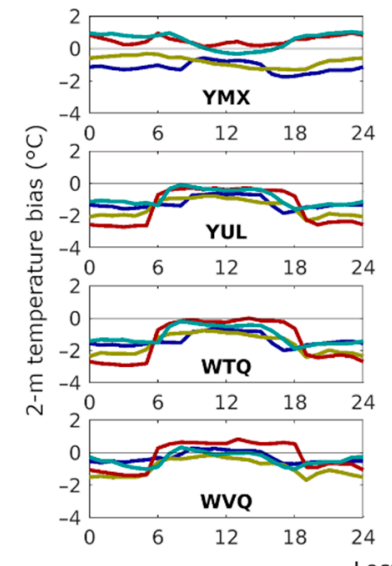

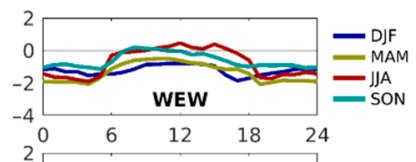
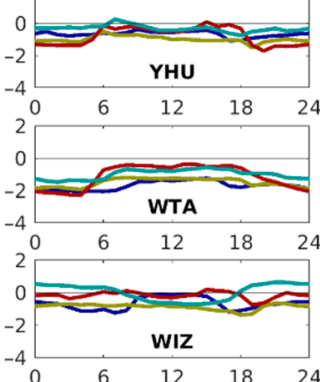
Local time
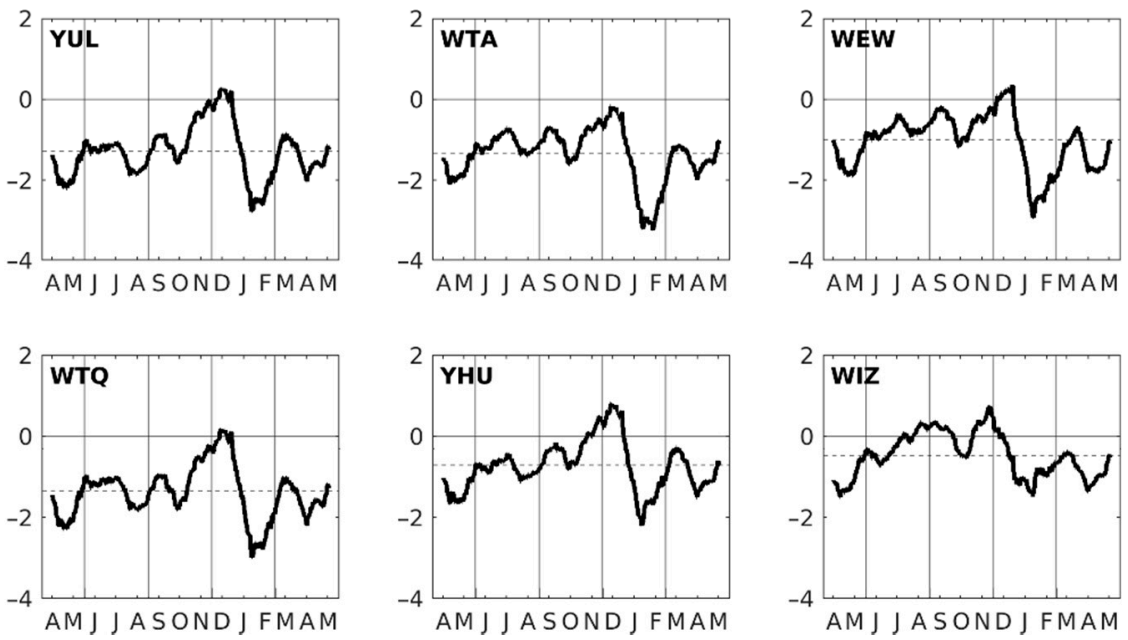

Figure 4. (a) Location of the $2 \mathrm{~m}$ temperature observation stations in the study domain. Station code, average bias, and root mean square error (RMSE) are shown for each station. (b) Daily cycle of the $2 \mathrm{~m}$ temperature bias for each season at each station. (c) Evolution of the 30-day moving average $2 \mathrm{~m}$ temperature bias at each station from April 2019 to May 2020. Dashed lines show the average bias during the entire period.

\subsection{Modelled Impact of COVID-19 on Urban Temperatures}

To assess the impact of the COVID-19 measures as implemented in Montreal, the $2 \mathrm{~m}$ air temperature at grid cells with heavy traffic is compared to the adjacent grid cells in the GEM_COVID simulation. The daily evolution of these differences is shown in Figure 5, where an abrupt decrease in the magnitude of these differences occurs in midMarch, caused by the activation of COVID-19 containment measures, modelled as an $80 \%$ reduction in heat fluxes associated with traffic. As expected, this decrease is largest for the grid cells with the heaviest traffic (above $25 \mathrm{~W} \mathrm{~m}^{-2}$ ). 


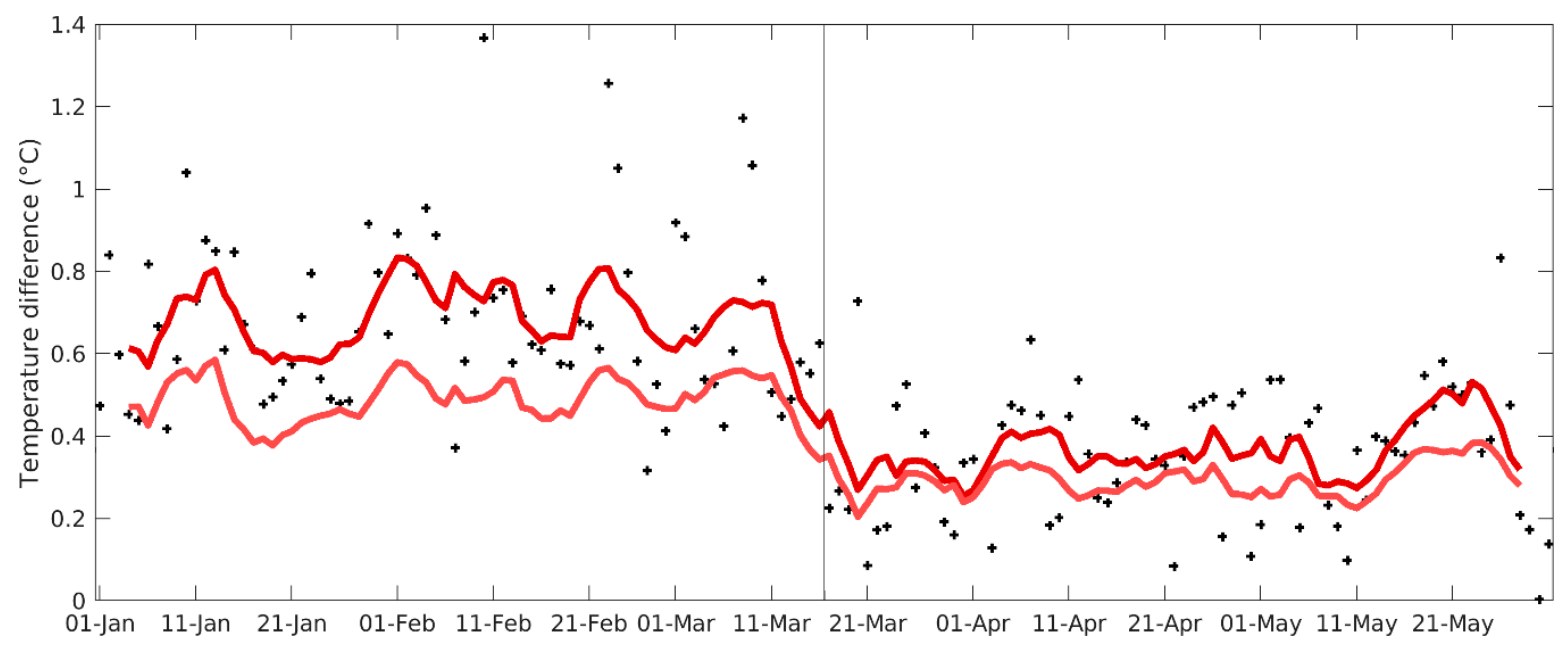

Figure 5. Daily evolution of maximum $2 \mathrm{~m}$ temperature differences between grid cells with sensible heat flux from traffic exceeding $25 \mathrm{~W} \mathrm{~m}^{-2}$ and adjacent cells for January to May 2020 in the GEM_COVID simulation (black symbols). The 7-day moving average is shown in dark red. The light red line shows the 7-day moving average for grid cells exceeding $10 \mathrm{~W} \mathrm{~m}{ }^{-2}$.

COVID-19 measures could be implemented at any time during the year, and their effects on urban climate are likely to vary by season and be reflected in various extremes. To understand the potential impacts throughout the year, the $2 \mathrm{~m}$ temperatures in the GEM100 and GEM20 simulations are compared for each season (Figure 6a-d). This comparison reveals that the $2 \mathrm{~m}$ temperature during the afternoon traffic peak is up to $1^{\circ} \mathrm{C}$ lower in the GEM20 simulation than in the GEM100 simulation for all seasons, with the differences being slightly larger in the autumn (SON) and winter (DJF) seasons (Figure $6 c, d)$. In all seasons, the differences in $2 \mathrm{~m}$ temperature are co-located with the road network, and the greatest differences occur for the grid cells with large heat fluxes from traffic (Figure 1a). Considering that heat fluxes from traffic usually account for between one third and one half of the total anthropogenic heat flux [38], these results are broadly consistent with previous studies which have shown that the total anthropogenic heat flux can increase the local near-surface air temperature by $\sim 1-2{ }^{\circ} \mathrm{C}$ in summer and $\sim 2-3{ }^{\circ} \mathrm{C}$ in winter [44-46].

The grid cells where the sensible heat flux from traffic exceeds $10 \mathrm{~W} \mathrm{~m}^{-2}$ contribute close to one third of the total heat flux for the region. Given that these grid cells also exhibit the largest temperature differences (Figure 6a-d), their data were used to assess the temporal variations in the difference between the GEM100 and GEM20 simulations. The greatest variation follows the daily cycle of traffic, with the temperature difference exhibiting the same morning and afternoon peaks as the heat flux from traffic (Figure 6e), although somewhat attenuated, as the heat flux varies by a factor of about 50 during the day, while the temperature difference varies by a factor around 10 . This attenuation can be explained by the heat storage of roads and buildings during the hours with the heaviest traffic load, heat which is subsequently released during hours with lower loads. In addition to the heat flux from traffic, the roughness of the urban region also plays an important role in controlling temperature differences at the local scale, with a lower roughness favouring a decreased vertical mixing, allowing enhanced near-surface warming due to the heat flux from traffic and thus leading to larger $2 \mathrm{~m}$ temperature differences (Figure $6 \mathrm{f}$ ).

Substantial day-to-day variations in the temperature difference between the GEM100 and GEM20 simulations can be partly explained by variations in wind speed, with lower wind speeds favouring less mixing, meaning that heat from traffic remains near the surface, increasing the temperature differences (Figure 7a). The vertical temperature gradient in the lowest atmospheric layer also plays a role, with positive gradients (i.e., atmospheric inversions) being associated with larger temperature differences, as the increased atmospheric stability suppresses vertical mixing (Figure $7 \mathrm{~b}$ ). As inversions are much more common during winter than during summer, this also explains the temperature differences being larger in winter. 

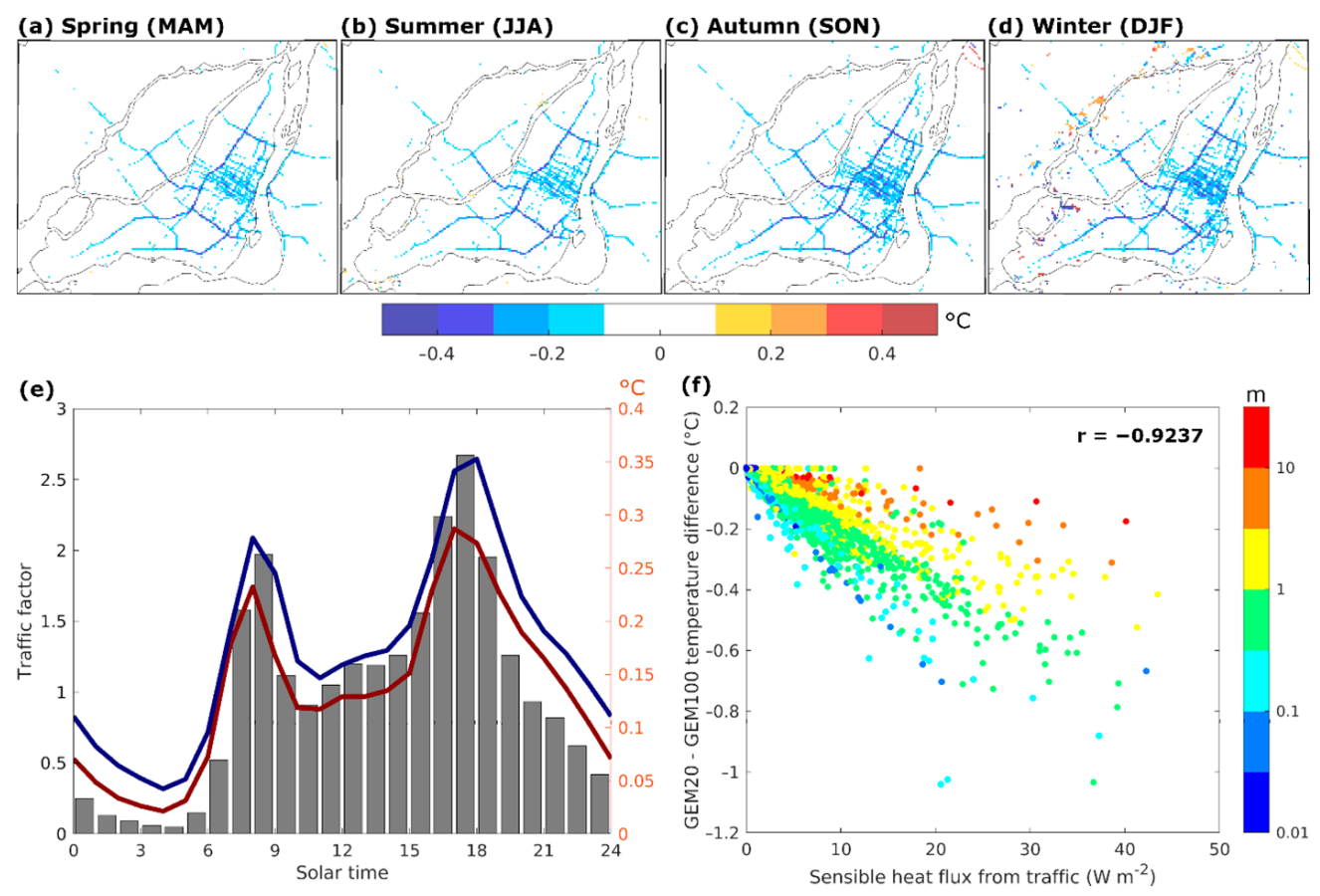

Figure 6. Average $2 \mathrm{~m}$ temperature difference at 5 p.m. local time (traffic peak) between the GEM20 and the GEM100 simulations for (a) spring, (b) summer, (c) autumn, and (d) winter. (e) Daily cycle of $2 \mathrm{~m}$ temperature differences between those simulations, during winter (DJF; blue) and summer (JJA; red), averaged for grid cells with sensible heat flux from traffic exceeding $10 \mathrm{~W} \mathrm{~m}^{-2}$. Gray bars show the multiplicative factor for heat flux from traffic for each hour of the day. (f) Median $2 \mathrm{~m}$ temperature difference at 5 p.m. local time for each grid cell as function of the sensible heat flux from traffic. Colours show the average roughness length of the urban fraction.
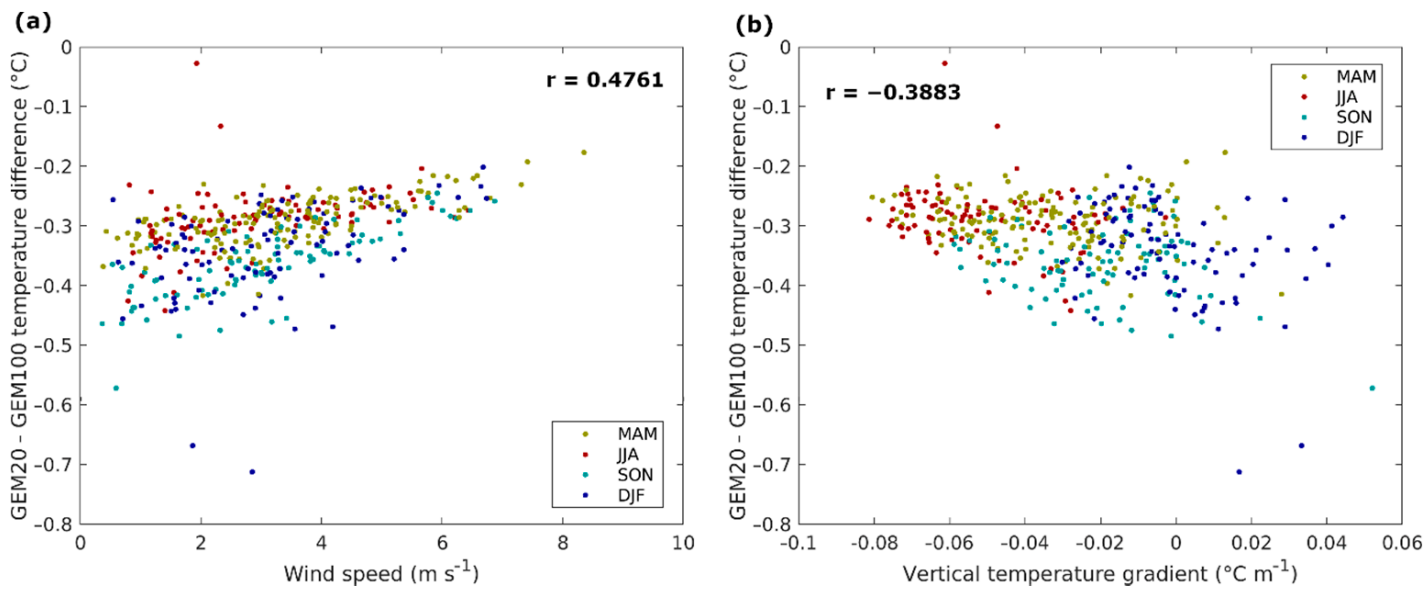

Figure 7. (a) Relationship between wind speed at 5 p.m. local time and GEM20-GEM100 2 m temperature difference at the same time, averaged over locations where the anthropogenic sensible heat flux due to traffic exceeds $10 \mathrm{~W} \mathrm{~m}{ }^{-2}$. (b) Relationship between near-surface vertical temperature gradient at 4 p.m. local time and GEM20-GEM100 $2 \mathrm{~m}$ temperature difference at 5 p.m. for the same locations. Different marker colors are used for different seasons: spring (MAM)—green; summer (JJA)—red; autumn (SON)—light blue; winter (DJF)—dark blue.

\subsection{Modelled Impact of COVID-19 on Extreme Weather}

As previously mentioned, increased heat stress in urban areas is widely recognized as the most important effect of the UHI on human health. Since heat stress is strongly linked to the near-surface air temperature, a hot hour is defined in this study as an hour where the $2 \mathrm{~m}$ temperature exceeds $30{ }^{\circ} \mathrm{C}$. During the simulation period, the median grid cell in 
urbanized areas experienced 111 hot hours in the GEM100 reference, compared to $70 \mathrm{~h}$ in non-urbanized areas (Figure 8a). The reduction in the heat flux from traffic resulted in reductions of up to $20 \%$ in hot hours in the GEM20 simulation, over those grid cells with large traffic fluxes (Figure 8b). The grid cells where the sensible heat flux from traffic exceeds $10 \mathrm{~W} \mathrm{~m}^{-2}$ experienced on average 8 fewer hot hours in the GEM20 simulation, with the greatest reductions during the afternoon traffic peak, where high temperatures coincide with heavy traffic. Similar reductions are observed if hot hours are defined as hours when the humidex exceeds 35 (Figure $8 \mathrm{c}, \mathrm{d}$ ). The humidex combines temperature and humidity information in an attempt to better approximate heat stress [13,47]. Given that the largest reductions in heat stress occur within traffic corridors, the users of active transportation (i.e., pedestrians and cyclists) would be among the most benefitted.
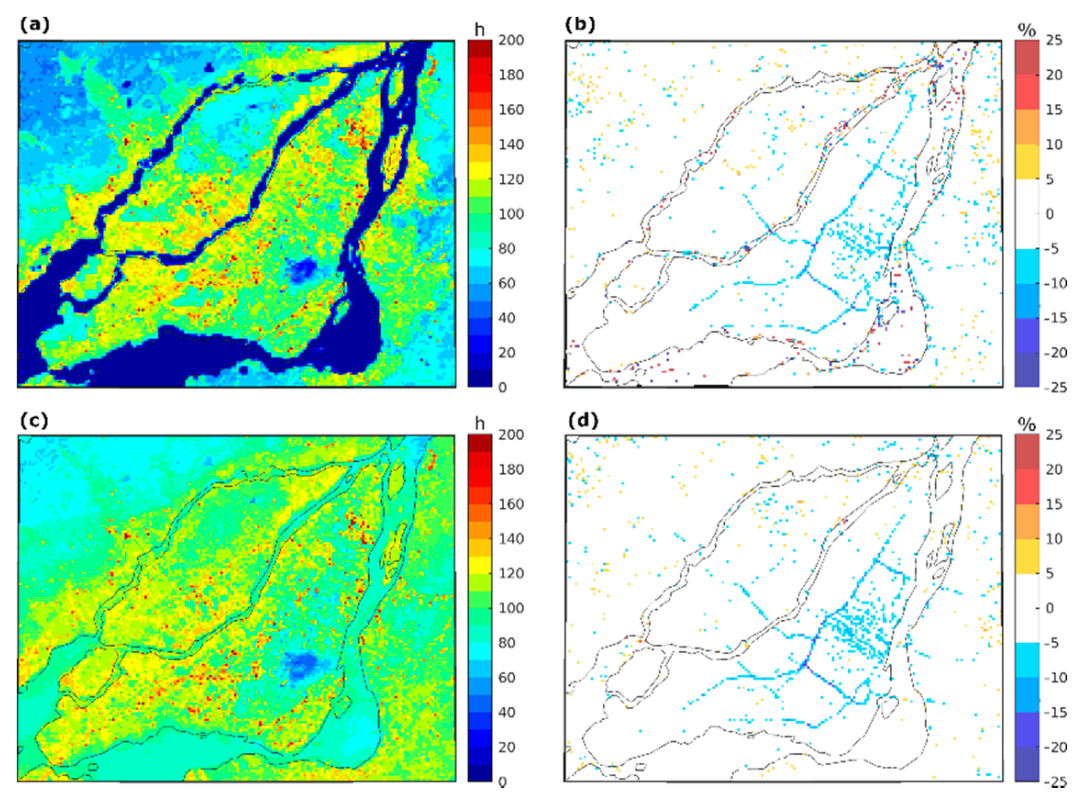

Figure 8. (a) Hours with $2 \mathrm{~m}$ temperature exceeding $30^{\circ} \mathrm{C}$ in the GEM100 simulation. (b) Relative difference in hours with $2-\mathrm{m}$ temperature exceeding $30^{\circ} \mathrm{C}$ between the GEM20 and the GEM100 simulations. (c) Hours with humidex exceeding 35 in the GEM100 simulation. (d) Relative difference in hours with humidex exceeding 35 between the GEM20 and the GEM100 simulations.

Freezing rain is major winter hazard, posing substantial dangers to surface transportation. Due to the UHI effect, urban regions usually experience reduced freezing rain compared to non-urban regions. In the reference GEM100 simulation, the median grid cell received $12 \mathrm{~mm}$ of freezing rain during the simulation period (Figure 9a). Lower accumulations are observed over highways and main roads due to the surfaces staying above $0{ }^{\circ} \mathrm{C}$, thus preventing the freezing of precipitation on impact. In the GEM20 simulation, the reduced heat flux from traffic results in cooler surfaces, increasing freezing rain accumulation by up to $50 \%$ (Figure $9 \mathrm{~b}$ ). Given that these greater accumulations would occur due to substantially reduced traffic, the overall number of traffic incidents would likely be lower for the duration of COVID-19 measures [48], but the essential traffic would be exposed to more hazardous road conditions. While road de-icing is routinely performed during freezing rain events, the expected increase in freezing rain accumulation due to reduced traffic needs to be taken into account when planning de-icing strategies under reduced traffic conditions, in particular with respect to the required amount of de-icing agents (salt and abrasives). 
(a)

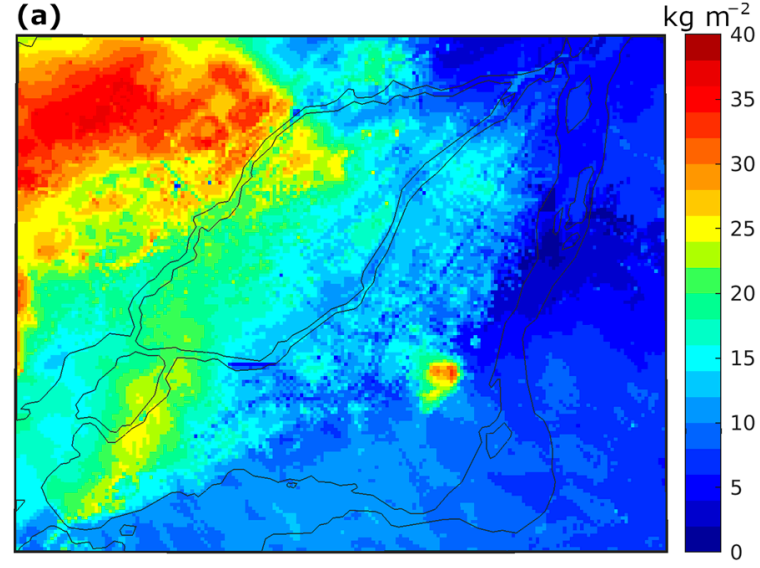

(b)

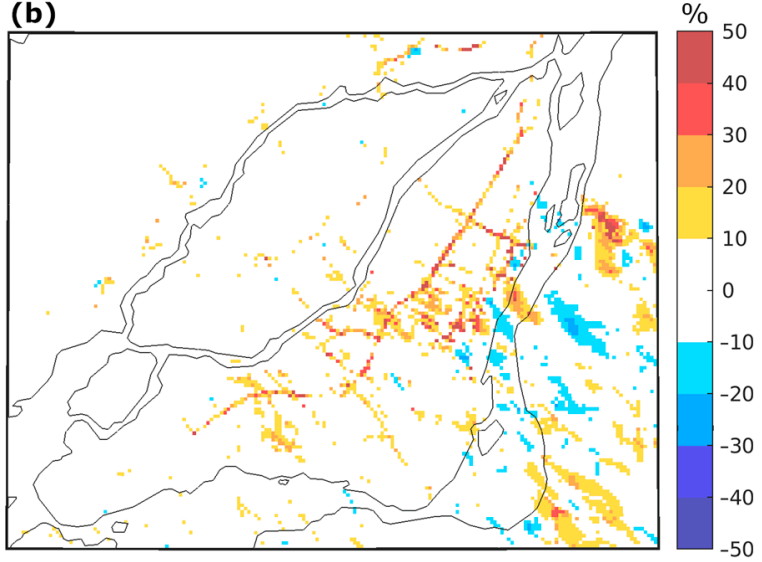

Figure 9. (a) Total freezing rain accumulation in the GEM100 simulation. (b) Relative difference in freezing rain accumulation between the GEM20 and the GEM100 simulations.

\section{Summary and Conclusions}

In this study, GEM simulations at a 250 m horizontal grid spacing were shown to be able to adequately capture the spatiotemporal variation in LST over Montreal and the surrounding areas when compared to estimates from MODIS, as well as the mean and variability of the $2 \mathrm{~m}$ air temperature at eight observing stations, performing especially well during summer daytime, when the strongest impacts of the UHI on human health occur. These urban climate simulations were then used to assess the impact of COVID-19 measures on urban temperatures, which here is assumed to occur through the substantial decrease observed in the usage of surface transportation, thus reducing the amount of heat emitted by traffic. The results show that an $80 \%$ reduction in the heat emitted by traffic corresponds to a decrease of up to $1{ }^{\circ} \mathrm{C}$ in the near-surface temperature for regions with heavy traffic. Weather conditions such as low near-surface wind speeds and temperature inversions in the surface layer were modelled to accentuate the contribution of traffic to the UHI, leading to the greatest reductions in urban temperatures. While modest, the reduction in near-surface temperatures is modelled to reduce hot hours by up $20 \%$ during the warm season, thus reducing heat stress for vulnerable populations, including pedestrians and cyclists. It is important to note that no substantial changes occur outside of traffic corridors. In the context of increasing temperatures due to global warming and potential adaptation/mitigation measures, these results indicate that potential reductions in traffic would need to be supplemented by additional measures to reduce the UHI effect and the associated heat stress.

Due to their computational cost and data availability considerations, GEM simulations were performed only for Montreal and its surroundings-a typical mid-latitude urban centre. Given the well-known physical mechanisms underlying the main findings of this study, most large urban centres around the globe are expected to exhibit a similar response to a reduction in surface traffic. This study only considers the direct effects of traffic-related emissions on urban temperatures. Indirect effects on temperature from aerosol and GHG reductions are likely to be close to negligible at the global scale, unless future emissions stay well below their pre-pandemic trajectory [20], but given their potential influence on the atmospheric radiation budget in the vicinity of urban regions, further study is merited.

Author Contributions: Conceptualization, L.S. (Laxmi Sushama) and B.T.; methodology, L.S. (Laxmi Sushama) and B.T.; software, V.P.; formal analysis, B.T.; investigation, V.P., B.T., and T.D.; resources, L.S. (Laxmi Sushama); writing-original draft preparation, B.T.; writing-review and editing, L.S. (Laxmi Sushama), S.B., L.M.-M., L.S. (Lijun Sun), A.P.S., G.B.; visualization, B.T.; supervision, L.S. (Laxmi Sushama); funding acquisition, L.S. (Laxmi Sushama). All authors have read and agreed to the published version of the manuscript. 
Funding: This research was funded by the Trottier Institute for Sustainability in Engineering and Design (TISED), the McGill Sustainability Systems Initiative (MSSI) and the Natural Sciences and Engineering Research Council of Canada (NSERC).

Institutional Review Board Statement: Not applicable.

Informed Consent Statement: Not applicable.

Data Availability Statement: The data presented in this study are available on request from the corresponding author.

Acknowledgments: The GEM simulations considered in this study were performed on supercomputers managed by Calcul Québec and Compute Canada.

Conflicts of Interest: The authors declare no conflict of interest.

\section{References}

1. Le Quéré, C.; Jackson, R.B.; Jones, M.W.; Smith, A.J.P.; Abernethy, S.; Andrew, R.M.; De-Gol, A.J.; Willis, D.R.; Shan, Y.; Canadell, J.G.; et al. Temporary reduction in daily global $\mathrm{CO}_{2}$ emissions during the COVID-19 forced confinement. Nat. Clim. Chang. 2020, 10, 647-653. [CrossRef]

2. Tan, J.; Zheng, Y.; Tang, X.; Guo, C.; Li, L.; Song, G.; Zhen, X.; Yuan, D.; Kalkstein, A.J.; Li, F.; et al. The urban heat island and its impact on heat waves and human health in Shanghai. Int. J. Biometeorol. 2010, 54, 75-84. [CrossRef]

3. Oke, T.R. The energetic basis of the urban heat island. Q. J. R. Meteorol. Soc. 1982, 108, 1-24. [CrossRef]

4. IPCC. Climate Change 2013: The Physical Science Basis. Contribution of Working Group I to the Fifth Assessment Report of the Intergovernmental Panel on Climate Change; Stocker, T.F., Qin, D., Plattner, G.-K., Tignor, M., Allen, S.K., Boschung, J., Nauels, A., Xia, Y., Bex, V., Midgley, P.M., Eds.; Cambridge University Press: Cambridge, UK; New York, NY, USA, 2013; p. 1535. [CrossRef]

5. Horton, R.M.; Mankin, J.S.; Lesk, C.; Coffel, E.; Raymond, C. A Review of Recent Advances in Research on Extreme Heat Events. Curr. Clim. Chang. Rep. 2016, 2, 242-259. [CrossRef]

6. Zhao, L.; Oppenheimer, M.; Zhu, Q.; Baldwin, J.W.; Ebi, K.L.; Bou-Zeid, E.; Guan, K.; Liu, X. Interactions between urban heat islands and heat waves. Environ. Res. Lett. 2018, 13, 034003. [CrossRef]

7. García-Herrera, R.; Díaz, J.; Trigo, R.M.; Luterbacher, J.; Fischer, E.M. A Review of the European Summer Heat Wave of 2003. Crit. Rev. Environ. Sci. Technol. 2010, 40, 267-306. [CrossRef]

8. Patz, J.A.; Campbell-Lendrum, D.; Holloway, T.; Foley, J.A. Impact of regional climate change on human health. Nature 2005, 438, 310-317. [CrossRef] [PubMed]

9. Alexandri, E.; Jones, P. Temperature decreases in an urban canyon due to green walls and green roofs in diverse climates. Build. Environ. 2008, 43, 480-493. [CrossRef]

10. Costanzo, V.; Evola, G.; Marletta, L. Energy savings in buildings or UHI mitigation? Comparison between green roofs and cool roofs. Energy Build. 2016, 114, 247-255. [CrossRef]

11. Touchaei, A.G.; Akbari, H. The climate effects of increasing the albedo of roofs in a cold region. Adv. Build. Energy Res. 2013, 7, 186-191. [CrossRef]

12. Hulley, G.; Malakar, N.; Freepartner, R. Moderate Resolution Imaging Spectroradiometer (MODIS) Land Surface Temperature and Emissivity Product (MxD21) Algorithm Theoretical Basis Document Collection-6; JPL Publication: La Cañada, CA, USA, 2016; pp. 12-17.

13. Ho, H.C.; Knudby, A.; Xu, Y.; Hodul, M.; Aminipouri, M. A comparison of urban heat islands mapped using skin temperature, air temperature, and apparent temperature (Humidex), for the greater Vancouver area. Sci. Total Environ. 2016, 544, 929-938. [CrossRef] [PubMed]

14. Chapman, S.; Watson, J.E.M.; Salazar, A.; Thatcher, M.; McAlpine, C.A. The impact of urbanization and climate change on urban temperatures: A systematic review. Landsc. Ecol. 2017, 32, 1921-1935. [CrossRef]

15. Joachim, F.; Stefan, E.; Peter, S. Mitigation of urban heat stress-a modelling case study for the area of Stuttgart. DIE ERDE J. Geogr. Soc. Berl. 2014, 144. [CrossRef]

16. Masson, V.; Lion, Y.; Peter, A.; Pigeon, G.; Buyck, J.; Brun, E. “Grand Paris": Regional landscape change to adapt city to climate warming. Clim. Chang. 2013, 117, 769-782. [CrossRef]

17. Leroyer, S.; Bélair, S.; Husain, S.Z.; Mailhot, J. Subkilometer Numerical Weather Prediction in an Urban Coastal Area: A Case Study over the Vancouver Metropolitan Area. J. Appl. Meteorol. Climatol. 2014, 53, 1433-1453. [CrossRef]

18. Li, Y.; Schubert, S.; Kropp, J.P.; Rybski, D. On the influence of density and morphology on the Urban Heat Island intensity. Nat. Commun. 2020, 11, 2647. [CrossRef]

19. Roberge, F.; Sushama, L. Urban heat island in current and future climates for the island of Montreal. Sustain. Cities Soc. 2018, 40, 501-512. [CrossRef]

20. Forster, P.M.; Forster, H.I.; Evans, M.J.; Gidden, M.J.; Jones, C.D.; Keller, C.A.; Lamboll, R.D.; Quéré, C.L.; Rogelj, J.; Rosen, D.; et al. Current and future global climate impacts resulting from COVID-19. Nat. Clim. Chang. 2020. [CrossRef] 
21. Huang, X.; Ding, A.; Gao, J.; Zheng, B.; Zhou, D.; Qi, X.; Tang, R.; Wang, J.; Ren, C.; Nie, W.; et al. Enhanced secondary pollution offset reduction of primary emissions during COVID-19 lockdown in China. Natl. Sci. Rev. 2020. [CrossRef]

22. Le, T.; Wang, Y.; Liu, L.; Yang, J.; Yung, Y.L.; Li, G.; Seinfeld, J.H. Unexpected air pollution with marked emission reductions during the COVID-19 outbreak in China. Science 2020, eabb7431. [CrossRef]

23. Menut, L.; Bessagnet, B.; Siour, G.; Mailler, S.; Pennel, R.; Cholakian, A. Impact of lockdown measures to combat Covid-19 on air quality over western Europe. Sci. Total Environ. 2020, 741, 140426. [CrossRef]

24. Muhammad, S.; Long, X.; Salman, M. COVID-19 pandemic and environmental pollution: A blessing in disguise? Sci. Total Environ. 2020, 728, 138820. [CrossRef]

25. Wang, Q.; Su, M. A preliminary assessment of the impact of COVID-19 on environment-A case study of China. Sci. Total Environ. 2020, 728, 138915. [CrossRef] [PubMed]

26. Zambrano-Monserrate, M.A.; Ruano, M.A.; Sanchez-Alcalde, L. Indirect effects of COVID-19 on the environment. Sci. Total Environ. 2020, 728, 138813. [CrossRef] [PubMed]

27. Côté, J.; Gravel, S.; Méthot, A.; Patoine, A.; Roch, M.; Staniforth, A. The Operational CMC-MRB Global Environmental Multiscale (GEM) Model. Part I: Design Considerations and Formulation. Mon. Weather Rev. 1998, 126, 1373-1395. [CrossRef]

28. Girard, C.; Plante, A.; Desgagné, M.; McTaggart-Cowan, R.; Côté, J.; Charron, M.; Gravel, S.; Lee, V.; Patoine, A.; Qaddouri, A.; et al. Staggered Vertical Discretization of the Canadian Environmental Multiscale (GEM) Model Using a Coordinate of the Log-Hydrostatic-Pressure Type. Mon. Weather Rev. 2014, 142, 1183-1196. [CrossRef]

29. Yeh, K.-S.; Côté, J.; Gravel, S.; Méthot, A.; Patoine, A.; Roch, M.; Staniforth, A. The CMC-MRB Global Environmental Multiscale (GEM) Model. Part III: Nonhydrostatic Formulation. Mon. Weather Rev. 2002, 130, 339-356. [CrossRef]

30. Laprise, R. The Euler Equations of Motion with Hydrostatic Pressure as an Independent Variable. Mon. Weather Rev. 1992, 120, 197-207. [CrossRef]

31. Milbrandt, J.A.; Yau, M.K. A Multimoment Bulk Microphysics Parameterization. Part I: Analysis of the Role of the Spectral Shape Parameter. J. Atmos. Sci. 2005, 62, 3051-3064. [CrossRef]

32. Verseghy, D.L. Class-a Canadian Land Surface Scheme for Gcms.1. Soil Model. Int. J. Climatol. 1991, 11, 111-133. [CrossRef]

33. Verseghy, D.L. CLASS-The Canadian Land Surface Scheme (Version 3.5); Technical Documentation (Version 1); Climate Research Division, Science and Technology Branch, Environment Canada: Gatineau, QC, Canada, 2011.

34. Masson, V. A Physically-Based Scheme for the Urban Energy Budget in Atmospheric Models. Boundary-Layer Meteorol. 2000, 94, 357-397. [CrossRef]

35. Ville de Montréal. Progress Report on Montréal's 2013-2020 Citywide Greenhouse Gas Emissions Reduction Plan; Service de l'environnement: Gatineau, QC, Canada, 2018.

36. Zahabi, S.A.H.; Miranda-Moreno, L.; Patterson, Z.; Barla, P. Spatio-temporal analysis of car distance, greenhouse gases and the effect of built environment: A latent class regression analysis. Transp. Res. Part A Policy Pract. 2015, 77, 1-13. [CrossRef]

37. Ville de Montréal. Déplacements MTL Trajet; Service de l'urbanisme et de la mobilité: Gatineau, QC, Canada, 2019.

38. Sailor, D.J.; Georgescu, M.; Milne, J.M.; Hart, M.A. Development of a national anthropogenic heating database with an extrapolation for international cities. Atmos. Environ. 2015, 118, 7-18. [CrossRef]

39. Waze. Waze COVID-19 Impact Dashboard; Waze Mobile Ltd.: Mountain View, CA, USA, 2020.

40. Hersbach, H.; Bell, B.; Berrisford, P.; Hirahara, S.; Horányi, A.; Muñoz-Sabater, J.; Nicolas, J.; Peubey, C.; Radu, R.; Schepers, D.; et al. The ERA5 global reanalysis. Q. J. R. Meteorol. Soc. 2020, 146, 1999-2049. [CrossRef]

41. Lemonsu, A.; Belair, S.; Mailhot, J. The New Canadian Urban Modelling System: Evaluation for Two Cases from the Joint Urban 2003 Oklahoma City Experiment. Boundary-Layer Meteorol. 2009, 133, 47-70. [CrossRef]

42. Leroyer, S.; Bélair, S.; Mailhot, J.; Strachan, I.B. Microscale Numerical Prediction over Montreal with the Canadian External Urban Modeling System. J. Appl. Meteorol. Climatol. 2011, 50, 2410-2428. [CrossRef]

43. Leroyer, S.; Bélair, S.; Spacek, L.; Gultepe, I. Modelling of radiation-based thermal stress indicators for urban numerical weather prediction. Urban Clim. 2018, 25, 64-81. [CrossRef]

44. Ma, S.; Pitman, A.; Hart, M.; Evans, J.P.; Haghdadi, N.; MacGill, I. The impact of an urban canopy and anthropogenic heat fluxes on Sydney's climate. Int. J. Climatol. 2017, 37, 255-270. [CrossRef]

45. Ichinose, T.; Shimodozono, K.; Hanaki, K. Impact of anthropogenic heat on urban climate in Tokyo. Atmos. Environ. 1999, 33, 3897-3909. [CrossRef]

46. Fan, H.; Sailor, D.J. Modeling the impacts of anthropogenic heating on the urban climate of Philadelphia: A comparison of implementations in two PBL schemes. Atmos. Environ. 2005, 39, 73-84. [CrossRef]

47. Davis, R.E.; McGregor, G.R.; Enfield, K.B. Humidity: A review and primer on atmospheric moisture and human health. Environ. Res. 2016, 144, 106-116. [CrossRef] [PubMed]

48. Chang, A.; Miranda-Moreno, L. Rethinking the Way We Move Beyond COVID-19. Available online: https://www.sae.org/ publications/technical-papers/content/wp-0012/ (accessed on 10 February 2021). 